\title{
研究課題別事後評価結果
}

1. 研究課題名「有機ナノ結晶の作製・物性評価と多元ナノ構造への展開」

2. 研究代表者名及び主たる研究参加者名 (研究機関名・職名は研究参加期間終了時点)

研究代表者

中西 八郎（東北大学多元物質科学研究所 教授）

主たる研究参加者

朝日 剛 (大阪大学 大学院工学研究科応用物理学専攻 助教授)

松田 宏雄 （(独）産業技術総合研究所 グループリーダー)

仁平 貴康 （日産化学工業(株電子材料研究所 主任研究員)

新井 邦夫 (東北大学大学院環境科学研究科環境科学専攻 教授)

堀米 操 (大日本インキ化学工業(株総合研究所 センター長)

宮下 陽介 （富士写真フィルム侏R\&統括本部先進コア技術研究所 研究員）

3. 研究内容及び成果

$3-1$. 研究の目的

物質・材料がナノサイズレベルに再構築されると、従来の物質分類の概念では捉えきれない新 しい特性を発現する新規な物質の創製と、そのような物質を対象とする新しい学術分野が登場す るであろうことを研究代表者は 90 年代初頭に指摘していた。

このような未踏分野の研究推進には、金属・半導体ナノ粒子に比べて、最も研究が遅れている 有機・高分子系のナノ結晶科学を速やかに進展させることが急務と考え、先ず、その作製法の探 索研究に着手した。その結果、有機ナノ結晶の作製手法として、純化学的な方法である「再沈 法」が汎用性に優れた有力な手法であることを世界に先駆けて発信すると共に、有機ナノ結晶固 有の興味深い現象・物性の一端を把握し報告した。

既に先導的展開を始めていた研究代表者らは、このような背景を踏まえて、有機ナノ結晶の基 礎科学分野のさらなる進展、加えて、金属・半導体のような異種物質・材料とのナノ複合化・多元 ナノ構造の創製および新たな応用展開を探る研究を戦略的に実施した。

\section{3-2. 研究構想}

これまでの有機・高分子コロイド粒子が基本的に非晶質・無定形であったのに対して、明確に 定義された有機ナノ結晶は本質的に異なる物質・材料系であり、その多様性、分子設計・合成の 容易さから、金属・半導体ナノ粒子と比較して、高い潜在的ポテンシャルを有する。さらに、異種 ナノ材料との多元ナノ構造化は、光・電子特性発現での新しいフェーズに繋がり、単に基礎科学 分野に止まらず、情報・通信分野等における新素材や新しい動作原理に基づくデバイスの提案 など、その波及効果は極めて大きいと言える。 
そこで、本研究開発の開始時には、以下の 3 つの目標を設定した。

1）再沈法をさらに完成度の高い作製技術として確立するための装置開発、そのための化学工 学的データの蓄積を行い、これにより、サイズ・形状が高度に制御された有機ナノ結晶の実 験室レベルでの大量合成を可能にする。

2）孤立分子とバルク結晶の中間に位置する有機ナノ結晶とそれをベースとする新規な「多元物 質から成るナノ構造体」の創製、構造・物性相関を解明し、有機ナノ結晶に特有の個性を明 らかにする。

3）有機ナノ結晶を用いることによる新たな応用の例証を行う。

平成 12 年度の採択・開始とともに、研究代表者が自ら率いる「中西グループ」では、金属など の異種材料とのハイブリッドナノ構造体の作製法も含めて、高度なサイズ・形状制御および実験 室レベルでの大量合成プロセスを目指して、有機ナノ結晶の作製法である再沈法の発展・改良を 進めた。さらに、有機ナノ結晶分散液「液・晶」系における電場配向制御とその固定化を推進し た。

$3-3$. 研究成果

$3-3-1$. 有機ナノ結晶の作製手法の探求・確立

既に見出していた「再沈法」をさらに発展・拡充させ、広汎な有機・高分子化合物のナノ結晶化 に有用な汎用的手法として確立できた。

再沈操作後のマイクロ波照射によって、試料である有機ナノ結晶分散系を極めて短時間 (秒

オーダー)に均一加熱することが可能となり、ナノ結晶化の促進、サイズの単分散化を飛躍的 に向上させた。これまでの手動による再沈操作をオートサンプラーを用いて行うことにより、有機ナ ノ結晶のサイズ・形状を繰り返し再現性良く制御、作製できた。さらに無脈流シリンジポンプを用い た再沈法システムを開発することにより、 $1.2 \mathrm{~g} / \mathrm{h}$ といら高効率での連続作製が可能となった。さら にまた、超臨界再沈法による、難溶性有機顔料などの連続プロセスによるナノ結晶の製造方法の 有用性を示した。

3-3-2. 有機・高分子ナノ結晶の個性の解明

サイズ、形状に依存したナノ結晶に特有の光学特性および化学特性の存在とそれらの原因を 明らかにした。加えて、多元ナノ構造化では、異種材料である金属とのナノ複合化により、加成性 を超えた電子状態が発現することを見出した。

ポリジアセチレンおよびペリレンナノ結晶の個々のサイズと分光スペクトルとを同時に測定を行 った結果、サイズ効果は弱い分子間力で結合した有機ナノ結晶特有の現象であることを始めて 明らかにした。また、ポリジアセチレンナノ結晶の生成過程、つまりその固相重合過程は、バルク 結晶と比較して転化率が向上し、重合開始までの誘導期は短縮されることが明らかとなった。また、 ナノ結晶を構成するポリジアセチレンの分子量分布は狭く、対応するバルク結晶より欠陥構造が 少ないと示唆された。一方、ジオレフイン誘導体ナノ結晶では、バルク結晶で見られた巨視的なク 
ラックの発生や崩壊は認められず、単結晶一単結晶相転移が進行し、モノマーとポリマーの結晶 格子に対応した形状変化が見られること等が分かった。

一方、コアーシェル型多元ナノ構造体の最初の例として、再沈法を拡張した「共沈法」を確立 することによって、銀-コア/ポリジアセチレンーシェルから構成されるハイブリッドナノ結晶の作製に 成功した。非常に興味深いことに、銀-コア由来の局在表面プラズモンがその共鳴周波数を変え ることなく、強度減衰・消失した。高輝度放射光を用いた光電子分光から、これはコアーシェル界面 で生じた強い化学的相互作用の結果、銀-コア界面が局所的に非金属化ドメインを形成、銀価電 子帯の自由電子の平均自由行程が減少するためと推定した。

3-3-3. 有機・高分子ナノ結晶を用いた新たな応用の例証

対象化合物の機能に応じた種々の材料化が可能なことを示せた。特に、従来技術とは全く異 なる再沈法で、難溶性色素・顔料の高品質化に道筋を開いたことは、関連工業分野への波及効 果が大きいと期待される。

(1)高分子電解質 (ポリカチオン) 水溶液とポリジアセチレンナノ結晶水分散液にガラス基板を順 次浸積することにより (Layer-by-Layer 法、静電吸着法)、散乱損失が少なく光学的に優れた有 機ナノ結晶薄膜を作製した。膜厚は浸積回数で容易に制御可能であり、このような累積薄膜では その濃縮効果によって、ポリジアセチレンの非線形光学定数の実質的向上が達成された。さらに、 浸積サイクル工程に銀ナノ粒子水分散液を加えるとポリジアセチレンナノ結晶と銀ナノ粒子からな る交互累積薄膜も作製可能である。その可視吸収スペクトルから、交互累積薄膜層間での電子 的相互作用が示唆された。

(2)再沈法で作製された有機ナノ結晶分散系は、等方的で散乱損失の少ない透明な液体では あるが、結晶としての性質を保持している(称して「液・晶」)。夜中でブラウン運動しているナノ結 晶を外場印加により配向制御することで、系の透過率(吸光度)を制御し、さらに固定化することで 擬似結晶としての機能化に成功した。

(3)フッ化ポリイミドは低誘電率材料として有望で、そのナノ粒子化の作製法を検討・確立した。 また、注入溶液であるポリアミック酸溶液に $\mathrm{LiCl}$ やポリアクリル酸を添加することでユニークな形状 の多孔性ポリイミドナノ粒子を作製することに成功した。

(4)再沈時、ポリアミド酸溶液に希土類硝酸塩を添加することで、有機・無機複合体である希土 類イオン(ユウロピウム或いはテルビウムイオン) 含有ポリイミドナノ粒子を作製した。その蛍光特性 は非常に興味深く、紫外光照射量の増加に伴い蛍光強度が増強して、一方、熱処理を施すこと によりその温度を感知・記憶して蛍光強度が減少・消失するという従来にない特異な発光挙動を 示すことを見出した。ポリイミ゙トマリックスから希土類イオンへのエネルギー移動を経て発光を示 すことも判明した。ナノ空間での紫外線照射量、温度センサーや画像記録媒体等、幅広い分野 への応用が期待される材料であるといえる。

4. 事後評価結果 
4-1. 外部発表(論文、口頭発表等)、特許、研究を通じての新たな知見の取得等の研究成果の状況

グループ全体として海外36件の論文発表を行った。招待講演は国内12件、海外21件、口頭 発表、ポスター発表は内容的に重複しているものを除き、国内 124 件、海外 83 件である。特許出 願は国内19件、海外6件であった。

4-2. 成果の戦略目標・科学技術への貢献

有機ナノ結晶の作製では、「再沈法」を発展・拡充させ広汎な有機・高分子化合物のナノ結晶 化に有用な汎用的手法として確立できた。また、個性の解明では、サイズ、形状に依存したナノ 結晶に特有の光学特性および化学特性の存在とそれらの原因を明らかにした。加えて、多元ナノ 構造化では、異種材料である金属とのナノ複合化により加成性を超えた電子状態が発現すること を見出した。さらに応用展開では、対象化合物の機能に応じた種々の材料化が可能なことを示し、 特に、従来技術とは全く異なる再沈法で難溶性色素・顔料の高品質化に道筋を開いたことは、関 連工業分野への波及効果はきわめて大きい成果と言える。

\section{4-3. その他の特記事項(受賞歴など)}

中西八郎研究代表者が、高分子科学功績賞 (平成16年度)を受賞した。その他、共同研究者 のうち、朝日 剛が光化学協会進歩賞 (平成13年)、笠井均がトーキン科学技術振興財団研究奨 励賞 (平成13年度)および日本化学会進歩賞 (平成13年度)を受賞した。

また、有機顔料ナノ結晶の新規製造プロセスの研究開発は、NEDO の「ナノテク・先端部材実 用化研究開発」(平成 17 年度開始) 事業に採択され、早期実用化に向けた研究開発が開始され ている。 